\title{
Desain Sistem Informasi Harga Pangan Realtime Sebagai Instrumen Kebijakan Pengendalian Inflasi Daerah
}

\author{
Rahman', Sry Wahyuni ${ }^{2)}$ \\ ${ }^{1,2}$ Laboratorium Sistem Informasi Fakultas Sains dan Teknologi UIN Alauddin Makassar ${ }^{1,2} \mathrm{Jl}$. \\ H. M. Yasin Limpo No.36, Samata-Gowa, 92113, Telp/Fax: 0411-841879 \\ E-mail: $\underline{\text { rahman.mallwaing@uin-alauddin.ac.id }}{ }^{1)}$,yuni maliek@gmail.com ${ }^{2)}$
}

\begin{abstract}
Abstrak - Tim Pengendalian Inflasi Daerah (TPID) dan juga masyarakat umum membutuhkan rujukan informasi harga pangan yang terpercaya sekaligus mudah diakses. Penelitian ini bertujuan membangun sebuah sistem informasi pangan untuk mendukung kerja pengendalian inflasi daerah yang telah menjadi program pemerintah. Sistem dikembangkan dengan mengacu pada standar kebutuhan pemantauan harga pangan oleh Tim Pengendalian Inflasi Provinsi Sulawesi Selatan. Arsitektur sistem memanfaatkan teknologi Cloud Computing dengan membangun jaringan Sistem Database dan Web Server virtual (virtual server) pada jaringan cloud. Arsitektur server database berbasis cloud berfungsi sebagai pusat data yang bisa diakses dari beragam antarmuka dari platform berbeda. pada tahap awal penelitian, sistem dibangun dengan 3 antarmuka akses ke server pusat data yaitu melalui aplikasi web akses publik (Front-End), akses operator/administrator (BackEnd) dan aplikasi Android yang juga bersifat publik. Sistem berjalan baik dalam menampilkan data harga per komoditas, statistik harga bulanan, metadata harga dan akses pengelolaan sistem oleh administrator. Sistem Informasi Harga Pangan sebagai produk penelitian akan memberi kontribusi langsung bagaimana menyelesaikan pemantauan hargadari cara manual menggunakan struktur sistem database server. Arsitektur sistem menggunakan teknologi cloud untuk implementasi sistem data-sentral bertujuan untuk menekan biaya. Model ini dapat menjadi rujukan bagi sistem serupa yang membutuhkan suatu implementasi data sentral yang handal dan berbiaya murah.
\end{abstract}

Kata Kunci: Sistem Informasi, TPID, Cloud Computing, Web Server, Database System, Front-End, Back-

End, Virtual Server.

\section{PENDAHULUAN}

Pada tahun 2008 pemerintah bersama dan melalui Bank Indonesia (BI) memberikan perhatian khusus terkait isu inflasi daerah melalui gagasan pembentukan Tim Pemantauan dan Pengendalian Inflasi Daerah (TPID). TPID beranggotakan Bank Indonesia (BI), Kementerian Koordinator Bidang Perekonomian (Kemenko), dan Kementerian Dalam Negeri (Kemendagri) melalui penandatanganan Nota

Kesepahaman (MoU) Nomor. MOU01/M.EKON/03/2011， 13/I/GBI/DKM/NK， 300-194 Tahun 2011. TPID telah beroperasi intens dan melakukan berulang pertemuan untuk menggagas solusi inflasi dan terutama pencegahannya. Saat ini telah terbentuk sekitar 93 TPID yang beroperasi di 33 provinsi.

Pada Rakornas TPID V 2014 tercipta tiga kesepakatan penting, yaitu meningkatkan kerjasama antar daerah di bidang ketahanan pangan melalui dukungan perencanaan program kerja dan penyediaan anggaran di daerah; meningkatkan ketersediaan dan kualitas data dan informasi surplus defisit pangan di setiap daerah oleh TPID untuk menjadi acuan dalam melakukan kerjasama antardaerah; dan meningkatkan kapasitas pengelolaan kerjasama antar daerah, antara lain melalui bimbingan dan konsultasi bagi TPID yang difasilitasi oleh Kelompok Kerja Nasional (Pokjanas) TPID. Kesepakatan tersebut, khususnya poin 
pengelolaan data, menjadi faktor pemicu daerah untuk mencari model sistem yang baik yang bisa mewujudkan ketersediaan dan kualitas data pangan yang baik.

Akhir tahun 2014 hingga sepanjang tahun 2015 dapat dipastikan bahwa setiap tim TPID yang berada didaerah akan berusaha mencari model perangkat lunak pengelolaan database harga pangan. Sebab sistem tersebut telah secara otomatis menjadi instrumen penggalian informasi inflasi untuk kepentingan pengambilan kebijakan. Selain itu, keberadaan sistem informasi pangan yang aktual dan tersedia secara online, juga akan memberikan dampak positif bagi masyarakat umum. Setiap individu dapat mengakses harga acuan dari sumber pemerintahan sebelum melakukan transaksi. Ini akan mencegah ketakutan tak berdasar tentang harga-harga bahan pokok yang seringkali dihembuskan pihak-pihak tak bertanggung jawab.

$\begin{array}{rrrr}\text { Sistem informasi } & \text { tersebut harus mampu } \\ \text { menyediakan data } & \text { akurat dan }\end{array}$ dipertanggungjawabkan dari sisi sumber data dan keabsahan. Integritas data penting mengingat ketidaktepatan informasi harga yang dirujuk konsumen malah dapat memunculkan masalah baru seperti konflik masalah harga karena perbedaan acuan. Tidak terbatas disitu, dampak politis-ekonomis adalah kerugian pembiayaan implementasi sistem karena tidak sebandingnya biaya dan manfaat yang diberikan sistem. Sistem yang diinisialisasi pemerintah jika gagal atau tidak akurat pun bisa menurunkan tingkat kepercayaan masyarakat yang mlemahkan posisi politis pemangku kebijkan dalam merumuskan kebijakan untuk kepentingan umum.

Karena sudut pandang tersebut, sistem informasi harga pangan nantinya akan memanfaatkan data-data harga pangan yang selama ini telah diawasi oleh tim TPID pemerintah provinsi, yang dalam kasus penelitian ini adalah lingkup pemerintah SulawesiSelatan.

\section{MASALAH PENELITIAN}

1. Bagaimana membangun sistem informasi pangan yang mampu merekam fluktuasi harga pangan sepanjang tahun dari berbagai komoditas pangan.

2. Bagaimana menyajikan informasi harga pangan setiap saat setiap tempat tanpa kendala jarak, tempat dan waktu kerja.
3. Bagaimana menyajikan harga pangan yang terbarukan secara mudah, cepat dan murah untuk masyarakat pada umumnya.

4. Bagaimana mengimplementasikan sebuah sistem informasi publik memanfaatkan teknologi yang telah digunakan luas dan akrab dengan masyarakat serta meminimalisir kendala tidak terampilnya pengguna dalam mengoperasikan sistem.

\section{TUJUAN PENELITIAN}

1. Membangun sistem informasi pangan berbasis web sehingga dapat diakses online setiap tempat dan setiap waktu.

2. Membangun sistem basis data sentral pada cloud sebagai struktur inti dokumentasi harga-harga pangan yang mampu merekam harga pangan setiap tempat dan setiap waktu.

3. Membangun sistem informasi yang berjalan pada perangkat bergerak sehingga memudahkan publik mengakses informasi setiap saat.

\section{MANFAAT PENELITIAN}

Kerterbukaan informasi harga pangan, kemudahan akses dalam membandingkan harga melalui sistem online yang tersaji dalam sistem informasi pengawasan harga pangan, akan menjadi alternatif informasi masyarakat dalam memantau tren harga dan inflasi di masyarakat. Karena itu, informasi harga pangan aktual yang tersedia dengan cara akses online dan melalui aplikasi android akan memberikan manfaat luas meliputi:

1. Sebagai sistem informasi referensi bagi pengambil kebijakan untuk mengetahui harga-harga bahan pokok disetiap pasar dan melakukan operasi pasar jika suatu bahan pokok mengalami kenaikan tidak wajar.

2. Sebagai instrumen kunci kebijakan pengendalian inflasi karena menyediakan data kelangkaan komoditas sehingga kenaikan harga bisa diantisipasi. Data harga pada sistem secara aktual akan memperlihatkan setiap selisih tidak normal terhadap beda harga antara pasar karena satu dan lain faktor.

3. Sebagai sarana komunikasi top manajemen di pemerintahan dengan petugas lapangan dalam mengantisipasi masalah pangan.

4. Sebagai sumber informasi harga pangan bagi masyarakat umum melalui aplikasi android yang tersedia melalui layanan gratis publik. 


\section{METODOLOGI PENELITIAN}

\section{A. Jenis Penelitian}

Jenis penelitian yang digunakan adalah penelitian deskriptif kuantitatif yaitu penelitian yang menggambarkan kondisi fakta secara sistematis dari objek penelitian. Penelitian deksriptif kuantitatif dilakukan untuk mengetahui apakah sistem informasi pangan untuk menyediakan informasi aktual secara online dengan sistem berbasis website dengan fitur akses aplikasi Android dapat memudahkan pengguna mengakses harga pangan sebagai tujuan penelitian yang hendak dicapai.

Dalam rumpun ilmu teknik informatika, komputer dan sistem informasi, pencapaian tujuan penelitian dengan perancangan perangkat lunak sebagai solusi pengelolahan data pangan, termasuk kedalam kategori jenis penelitian rekayasa yang menggunakan teknik rancangan dan evaluasi. Rancangan merupakan proses desain sistem berdasarkan syarat fungsional dan syarat teknis sistem yang dirumuskan pada tahap analisa dan pengumpulan data. Sedangkan tahap evaluasi menjadi langkah untuk menguji pencapaian tujuan penelitian dalam memecahkan rumusan masalah setelah tahap implementasi sistem.

\section{B. Metode Pengumpulan Data}

Metode penelitian yang akan digunakan adalah Field Research dan Library Research. Sebagai tahap awal penelitian dilakukan dengan menentukan System Requirement Spesification (SRS). Tahap tersebut dilalui dengan merujuk pada berbagai penelitian sebelumnya dan dengan mempertimbangkan fungsional sistem. Selanjutnya mengumpulkan data implementasi sistem, kinerja, dan respon sistem terhadap permintaan pengguna. Secara garis besar metode pengumpulan data caranya melalui

\section{Penelitian Lapangan (Field Research) yang meliputi :}

a. Observasi yaitu melakukan pengamatan secara langsung pada obyek sistem yang akan diteliti dan dibahas serta mengumpulkan data atau informasi yang sebanyak mungkin yang berhubungan dengan masalah yang akan diteliti.

b. Wawancara yaitu melakukan wawancara untuk mengumpulkan informasi tentang sistem dari pengguna sistem atau pihak yang berkepentingan dengan fungsional sistem. Semua itu dikaitkan dengan isuisu yang ingin dipecahkan dengan keberadaan sistem.

2. Penelitian Perpustakaan (Library Research), $y$ aitu penelitian yang dilakukan berpedoman pada buku atau literatur yang berhubungan dengan penelitian yang dilakukan. Penelitian pustaka dilakukan untuk mendukung tahap desain dan analisis persyaratan sistem. Tahap ini lebih banyak mengacu pada rekam jejak penelitian dalam pengembangan perangkat lunak yang telah terdokumentasi.

\section{Pengujian dan Evaluasi Perangkat Lunak}

Pengujian sistem akan menggunakan metode blackbox untuk mendeteksi kesalahan logika. Indentifikasi dilakukan melalui verifikasi output dan kelakuan sistem terhadap input yang distimulasikan. Sistem dinilai berhasil jika memiliki luaran sesuai ekspektasi, serta dalam prosesnya memperlihatkan prilaku antarmuka sistem dan tampilan data yang normal. Pendekatan pengujian black-box menitikberatkan pengujian pada kinerja dan fungsional sistem tanpa melihat ketepatan logika secara detail. Suatu test-case dipandang sukses jika menghasilkan luaran yang diingnikan tanpa perlu meninjau setiap rincian proses yang terjadi pada bagian perangkat lunak yang memproses input.

Pengujian perangkat lunak akan menguji beberapa hal yang berkaitan dengan syarat spesifikasi perangkat lunak yang diuraikan pada persyaratan fungsional sistem. Pengujian dilakukan dengan menetapkan kasus uji untuk setiap target yang dikehendaki dari prilaku luaran sistem. Jika pengujian itu berkaitan dengan fungsional sistem, maka penilaian kesuksesan sistem diukur dari syarat fungsional dari dokumen SRS yang telah ditetapkan. Sedangkan jika pengujian tersebut berkaitan dengan respon sistem terhadap suatu permintaan layanan informasi, maka penilaian kesuksesan sistem ditinjau dari 2 aspek standar kinerja sistem online yaitu ketepatan informasi yang diterima dan waktu respon sistem sejak pertama permintaan itu dieksekusi dari sisi komputer klien. Penulis menjelaskan secara sistematis mengenai metodemetode yang digunakan atau desain sistem yang dibangun untuk penelitian. Metodologi penelitian dapat berisi rancangan/model, pengukuran dan definisi operasional variabel, sampel dan data, tempat dan waktu, tekni dengan hipotesis (jika perlu). Hasil dibahas dengan mengacu pada rujukan yang digunakan. 


\section{HASIL DAN PEMBAHASAN}

\section{A. Waktu dan Tempat Penelitian}

Penelitian ini dilakukan pada dua tempat berbeda yaitu pertama pada Kantor Pemerintah Provinsi Sulawesi Selatan dan kedua pada Laboratorium Kampus Universitas Negeri Islam Alauddin Fakultas Sains Dan Teknologi. Tempat pertama merupakan sumber data penelitian berupa harga pangan. Sedangkan tempat penelitian kedua sebagai lokasi pengembangan perangkat lunak, pengujian dan implementasi sistem secara online.

Penelitian dilaksanakan pada bulan Maret 2016 sampai bulan Agustus 2016 melalui rangkaian tahap penelitian; Analisa, Desain, Implementasi dan Testing. Penelitian dimulai setelah tahap identifikasi umum permasalahan hingga perumusan gagasan penyelesaian. Penguatan ide terjadi pada bulan Maret melalui studi kepustakaan berkaitan dengan penelitian sistem informasi online menggunakan teknologi cloud computing. Tahap analisa dan desain dilakukan beriringan dengan proses pengumpulan data pada bulan April hingga pertengahan Mei. Tahap akhir adalah tahap implementasi, testing dan integrasi sistem.

\section{B. Pengumpulan dan Analisa Data}

Data harga pangan bersumber dari data rekaman provinsi sulawesi selatan. Pemantauan dilakukan rutin terhadap 3 pasar utama, yaitu Pasar Pabaeng-Baeng, Pasar Terong dan Pasar Daya
Dalam proses pengumpulan dan analisa data ditemukan bahwa sistem arsip digital dalam bentuk berkas-berkas terpisah memiliki banyak kelemahan.

Kelemahan ini perlu diselesaikan melalui sistem baru yang akan dikembangkan. Diantara kelemahankelemahan tersebut adalah:

1. Sistem berkas digital sangat tergantung pada operator yang mengelolah file tersebut. Hanya yang bersangkutan yang mengetahui persis dimana menyimpan file-file data yang memuat informasi harga pada satu bulan. Demikian pula hanya yang berangkutan yang memiliki data backup.

2. File-file berkas sangat sulit dikelolah. Duplikasi berkali-kali suatu file bisa mengakibatkan kebingungan terhadap versi paling baru dan benar dari beberapa salinan file.

3. File berkas faktanya sangat rentan terserang virus komputer digital. Resiko ini terjadi karena sistem rekam digital yang tercetak secara langsung pada disk penyimpanan tanpa proteksi akses seperti yang disediakan jika menggunakan sistem database.

4. Data dalam bentuk file sulit dibagikan ke publik tanpa duplikasi data. Persoalannya adalah bagaimana menjamin semua orang yang mengakses file tersebut memiliki salinan

\begin{tabular}{|c|c|c|c|c|c|c|c|c|c|c|c|c|c|}
\hline ID & $\operatorname{tg} \mid$ & Jenis & Komoditi & sat & Terong & Pabaeng2 & Daya & sambung & j sentral & HRG RATA & G RATA & naikan & persentas \\
\hline & $8 / 30 / 2016$ & Beras & Beras Mec & & 9500 & 10000 & 9600 & & & 9700 & 9700 & 0 & 0 \\
\hline & $8 / 30 / 2016$ & Beras & Beras Prei & & 10500 & 12000 & 12800 & & & 11767 & 11767 & 0 & 0 \\
\hline & $8 / 30 / 2016$ & Beras & Beras Ket: & & 12000 & 15000 & 14000 & & & 13667 & 13667 & 0 & 0 \\
\hline & $8 / 30 / 2016$ & Jagung $\mathrm{Pi}$ & i Jagung Pi & $\mathrm{Kg}$ & 5000 & 4000 & 5000 & & & 4667 & 4667 & 0 & 0 \\
\hline & $8 / 30 / 2016$ & Kedele & Kedele & $\mathrm{Kg}$ & 12000 & 12000 & 15000 & & & 13000 & 13000 & 0 & 0 \\
\hline & $8 / 30 / 2016$ & Kacang Ta & Kacang Ta & $\mathrm{Kg}$ & 27000 & 28000 & 28000 & & & 27667 & 27667 & 0 & 0 \\
\hline & $8 / 30 / 2016$ & Ubi Kayu & Ubi Kayu & $\mathrm{Kg}$ & 4000 & 5000 & 5000 & & & 4667 & 4667 & 0 & 0 \\
\hline & $8 / 30 / 2016$ & Ubi Jalar & Ubi Jalar & $\mathrm{Kg}$ & 5000 & 5000 & 5000 & & & 5000 & 5000 & 0 & 0 \\
\hline & $8 / 30 / 2016$ & Daging Sa & a Daging Sa| & $\mathrm{Kg}$ & 85000 & 90000 & 95000 & & & 86667 & 90000 & 3333 & 4 \\
\hline & $8 / 30 / 2016$ & Daging Sa & a Daging Sa| & $\mathrm{Kg}$ & 90000 & 100000 & 100000 & & & 93333 & 90000 & -3333 & -4 \\
\hline & $8 / 30 / 2016$ & Daging Ay & Daging Ay & $\mathrm{Kg}$ & 30000 & 28000 & 30000 & & & 27667 & 96667 & 69000 & 249 \\
\hline & $8 / 30 / 2016$ & Telur Ayaı & ITelur Ayar & & 21000 & 20000 & 19000 & & & 19500 & 29333 & 9833 & 50 \\
\hline & $8 / 30 / 2016$ & Gula Pasir & r Gula Pasir & $\mathrm{Kg}$ & 14000 & 15000 & 15000 & & & 14667 & 20000 & 5333 & 36 \\
\hline & $8 / 30 / 2016$ & Gula Pasir & r Gula Non & $\mathrm{Kg}$ & 13000 & 13000 & 13500 & & & 13167 & 14667 & 1500 & 11 \\
\hline & $8 / 30 / 2016$ & Minyak Gc & cCurah & Ltr & 11000 & 10000 & 10000 & & & 10333 & 13167 & 2833 & 27 \\
\hline & $8 / 30 / 2016$ & Minyak Gc & (Bimoli & Ltr & 16000 & 15000 & 15000 & & & 15333 & 10333 & -5000 & -33 \\
\hline & $8 / 30 / 2016$ & Terigu & Kompas ( $\mathrm{H}$ & $\mathrm{Kg}$ & 9000 & 9000 & 10000 & & & 9333 & 15333 & 6000 & 64 \\
\hline & $8 / 30 / 2016$ & Terigu & Gatot & $\mathrm{Kg}$ & 7000 & 7000 & 7500 & & & 7167 & 9333 & 2167 & 30 \\
\hline & $8 / 30 / 2016$ & Cabe & Cabe Mer: & $\mathrm{Kg}$ & 25000 & 25000 & 18000 & & & 23333 & 7167 & -16167 & -69 \\
\hline & $8 / 30 / 2016$ & Cabe & Cabe Mer: & & 35000 & 32000 & 30000 & & & 31667 & 22667 & -9000 & -28 \\
\hline & $8 / 30 / 2016$ & Cabe & Cabe Raw & & 25000 & 20000 & 20000 & & & 21667 & 32333 & 10667 & 49 \\
\hline & $8 / 30 / 2016$ & Bawang $\mathrm{N}$ & Bawang $\mathrm{N}$ & & 20000 & 20000 & 18000 & & & 19333 & 21667 & 2333 & 12 \\
\hline & $8 / 30 / 2016$ & Bawang $\mathrm{P}$ & Bawang PI & Kg & 20000 & 20000 & 20000 & & & 20000 & 19333 & -667 & -3 \\
\hline & $8 / 30 / 2016$ & Ikan Teri ( & ( Ikan Teri ( & & 75000 & 80000 & 80000 & & & 78333 & 20000 & -58333 & -74 \\
\hline
\end{tabular}

Gambar 1 Data Manual Harga Pangan

(Gambar 1 Data Manual Harga Pangan).

yang sama tanpa ada perbedaan sedikitpun. C.

Analisa dan Desain Perangkat Lunak 
Analisa sebagai tahap proses pengembangan program dilakukan berbeda dengan analisa data pada

tahap pengumpulan data. Pada tahap pengumpulan data fokus analisa adalah terhadap kondisi existing dengan kekurangan-kekurangan yang ada serta peluang adanya solusi untuk menutupi kekurangan dan menambah nilai lebih data dengan kehadiran perangkat lunak sistem informasi harga pangan. Sedangkan analisa dan desain mencari bentuk solusi praktis implementatif untuk menyelsaikan permasalahan.

Hasil proses analisa adalah sebuah dokumen persyaratan perangkat lunak yang menjadi panduang pengembangan perangkat lunak. pada penelitian ini, dokumen perangkat lunak yang ditetapkan tidak dalam bentuk format standar IEEE tapi hanya mengambil bagian penting yang berkenaan dengan pengembangan perangkat lunak. sedangkan proses desain menghasilkan diagram awal model perangkat lunak seperti diagram kelas, digram entitas, use case dan lainnya.

\section{Implementasi dan Perangkat Pengembangan Perangkat Lunak.}

Pengembangan perangkat lunak menggunakan pendekatan formal dengan tahap dasar pengembangan perangkat lunak yakni Analisis, Desain, Implementasi, Pengujian. Proses desain mengacu pada hasil analisis terhadap persyaratan perangkat lunak melalui 3 sumber acuan utama. Rujukan tersebut tersebut yaitu 1. Syarat integrasi data menurut amanah peraturan TPID, 2. Penyesuaian kondisi data rekap harga pangan selama tahun 2015 dan 2016 yang dimiliki dinas provinsi, dan 3. Syarat sistem melalui wawancara dengan tim operator pengendalian harga pangan provinsi sulawesi selatan.

Perangkat lunak dikembangkan menggunakan tools pengembangan open-source. Program ditulis dalam bahasa PHP yang merupakan bahasa pemrograman populer. Database sistem dikelola menggunakan MYSQL server. Beberapa kakas bantu digunakan selama pengembangan proyek. Desain database dan rancangan diagram entitas menggunakan MYSQL Workbench. Sedangkan desain Unified Modeling Language menggunakan AgroUML.

\section{E. Software Requirement Specification (SRS)}
a. Persyaratan Fungsional
1. Fungsi Menampilkan Harga Ril Harian

2. Fungsi Melihat Harga Pangan Per Komoditas

3. Fungsi Melihat Harga Pangan Suatu Pasar
4. Fungsi Melihat Harga Pangan Menurut Kategori Sejenis

5. Fungsi Melihat Harga Pangan Menurut Tanggal

6. Fungsi Melihat Statistik Harga Dalam Grafik

7. Fungsi Unduh Metadata Harga

8. Fungsi Input Data Pangan Oleh Operator

9. Fungsi Input Harga Pangan Oleh Operator 10. Fungsi Mengelola Data Oleh Operator

b. Persyaratan Antarmuka Sistem 1. Pengguna Umum Mengakses Harga Melalui Web Browser

2. Pengguna Perangkat Bergerak Dapat Mengakses Sistem Melalui Aplikasi Android

3. Operator Mengelola dan Memperbarui Data Melalui Halaman Web Admin

c. Persyaratan Teknis dan Perangkat Keras

1. Sistem Harus Berjalan Normal dengan 1000 Pengguna Bersamaan

2. Sistem Berjalan Pada Koneksi Standar Speedy 1 MBPS Shared Bandwidth

3. Sistem Menggunakan Platform

Microsoft Windows

4. Sistem Menggunakan Server Dengan Biaya Maksimal 2 Juta Per Bulan

5. Sistem Beroperasi 24 Jam selama 7 hari dalam sepekan.

\section{F. Entity Relationship Diagran}

a. Database Entities

Entitas pokok sistem meliputi, kelompok pangan, pangan, pasar, harga dan kota atau kabupaten. Entitas tambahan diperlukan untuk memperkaya informasi sistem seperti foto pasar, kontak, operator dan berita. Skema basis data di rancang menggunakan kakas workbench 5.0. Desain workbench mewakili struktur relasi entitas dalam sistem.

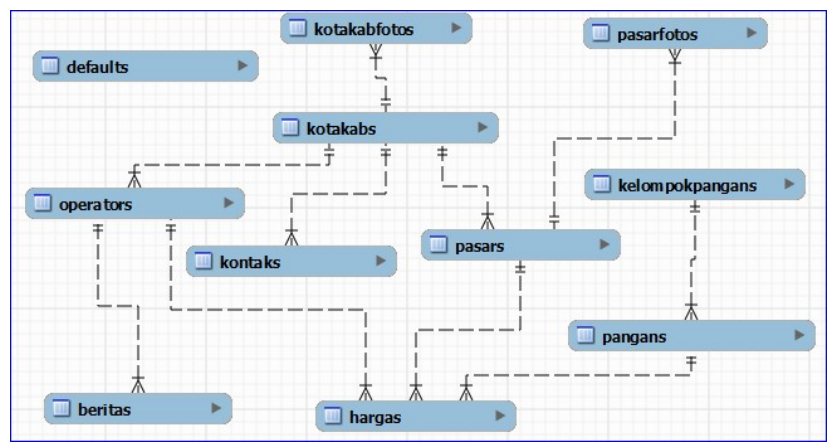

Gambar 2 Entity Relationship Diagram

b. Table Entities

Tahap selanjutnya adalah menerjemahkan diagram ERD kedalam tabel basis data. Proses ini juga dilakukan menggunakan kakas workbench. Penggunakan kakas yang sama sangat membantu dokumentasi proses perangkat lunak. Fitur forward 
dan reverse engineering mendukung konsistensi desain dan implementasi sistem database pada server.

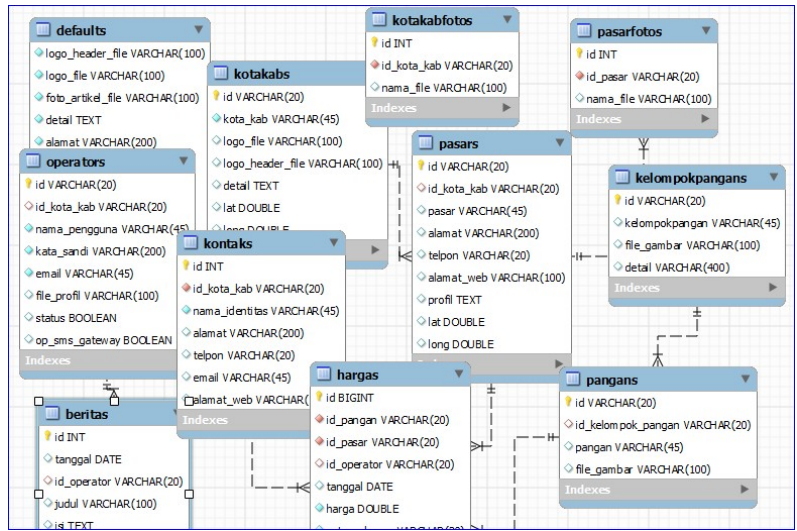

Gambar 3 Desain Tabel Sistem

\section{G. Use Case Diagram}

Deskripsi proses-proses utama pada sistem berikut aktor-aktor yang terlibat dituangkan dalam diagram Use Case.

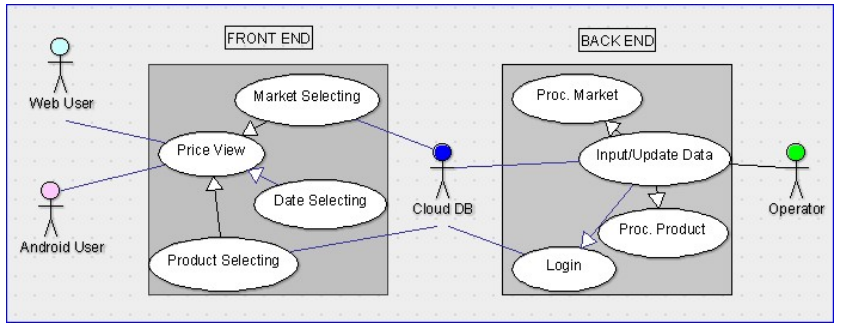

Gambar 4 Use Case Diagram

\section{H. Class Diagram}

Class Diagram adalah model yang menjembatani perbedaan struktur database dengan representasi data pada sisi aplikasi. model ini sekaligus sebagai panduan menulis kode sumber aplikasi dengan bahasa pemrograman yang digunakan.

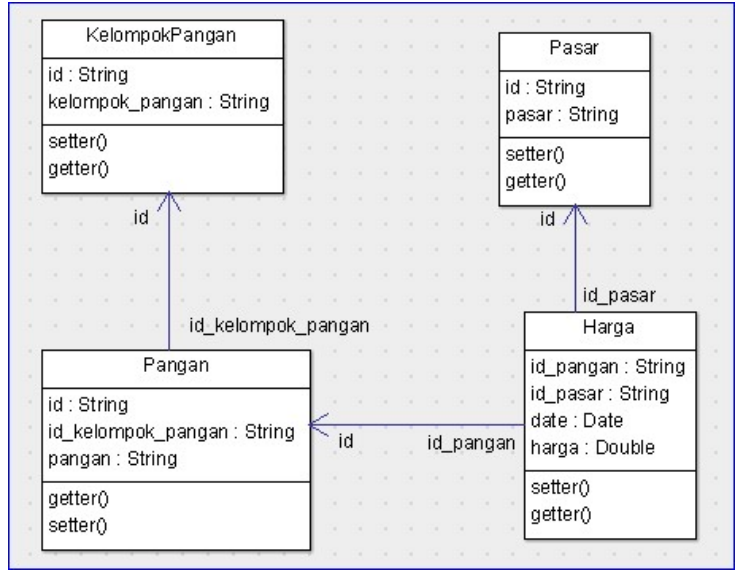

Gambar 5 Class Diagram

\section{Application Diagram}

Sistem informasi pangan menggunakan arsitektur sistem yang online. Baik server web maupun server database tersimpan pada cloud.

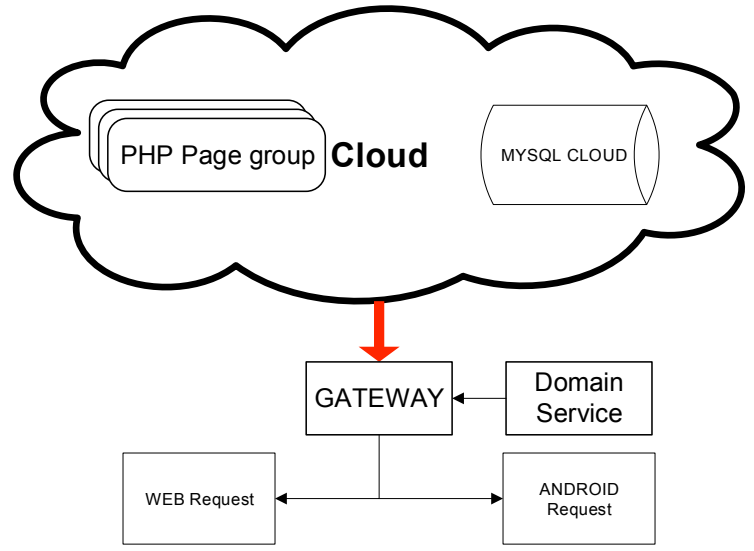

Gambar 6 Arsitektur Sistem

Sistem berbasis web terdiri atas 2 modul utama, yaitu modul akses publik yang berisi hargaharga pangan dan statistik menurut waktu dan pasar, dan modul pengelolaan admin sebagai halaman khusus operator untuk melakukan pembaharuan data harga pangan. Modul pengelolaan sistem dapat diakses melalui sub domain admin.uin-research.com.

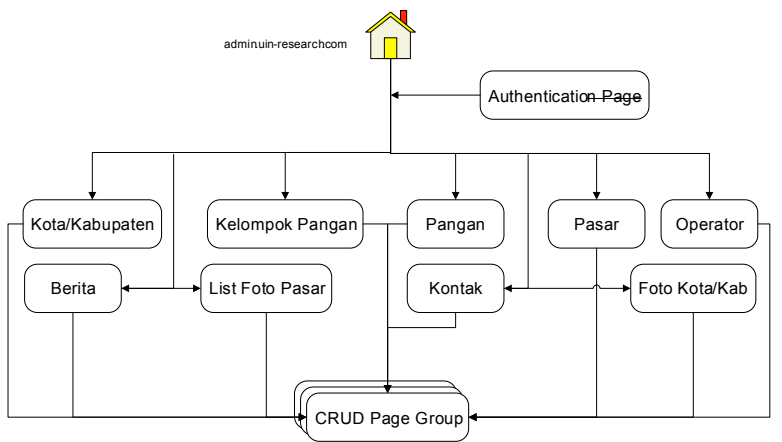

Gambar 7 Menu Halaman Admin

Modul admin pada dasarnya memiliki menu yang mirip dengan menu modul publik, namun pada modul admin terdapat koleksi halaman CRUD (Create, Read, Update, Delete) untuk mengelola setiap data yang diinput.

Halaman front-end sebagai halaman interaksi publik hanya menyajikan data informasi pangan tanpa ada pilihan untuk melakukan modifikasi. 


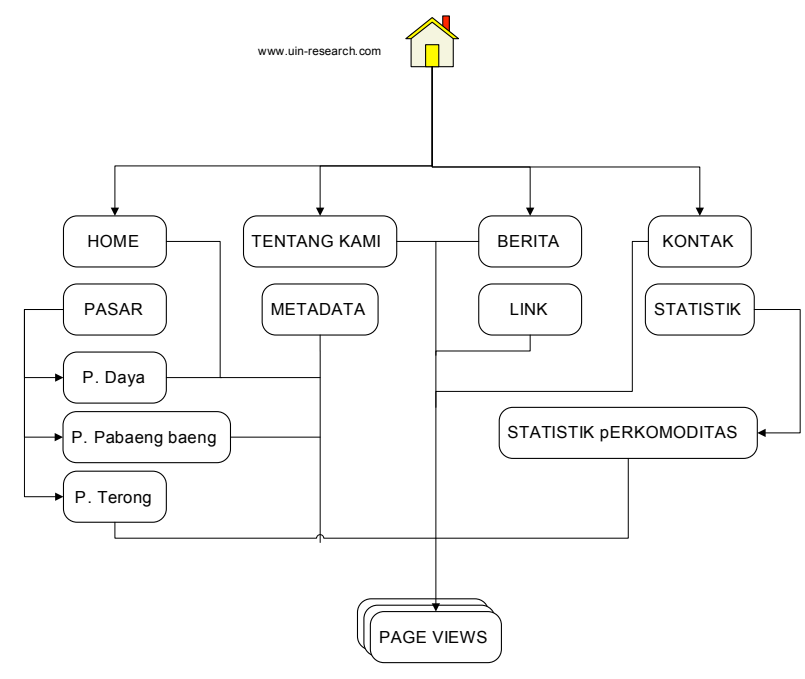

Gambar 8 Halaman Front-End

Antarmuka interaksi publik yang berbasis perangkat bergerak tersedia untuk pengguna Android. Baik sistem android, web publik dan web admin terhubung pada satu database sistem yang sama. Setiap aplikasi akan memperoleh pembaruan data begitu operator admin sistem melakukan pembaharuan data.

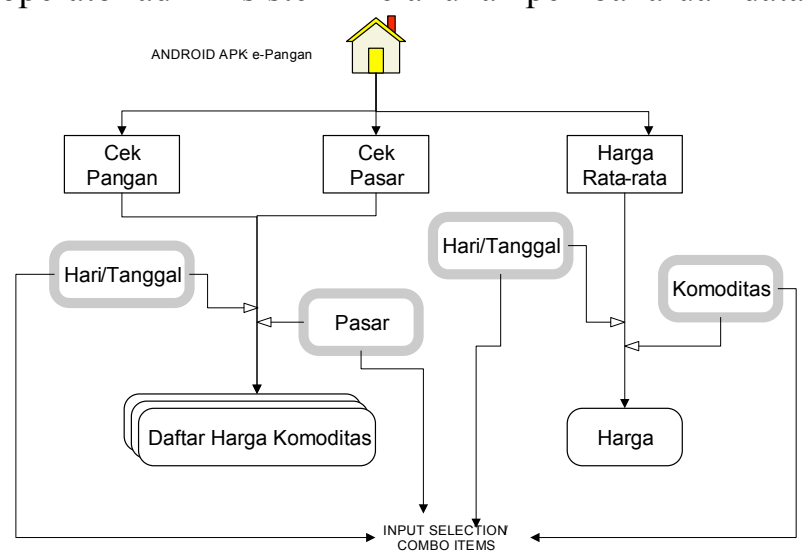

Gambar 9 e-Pangan Android

\section{J. Pengujian Sistem Online}

Pengujian sistem dilakukan dengan menetapkan standar kualitas perangkat lunak yang akan diuji beserta kasus uji yang akan dilakukan. Penetapan poin-poin pengujian dilakukan menurut dokumen persyaratan perangkat lunak. Secara garis besar dari proses perangkat lunak, pengujian pada tahap ini bermaksud untuk mengevaluasi hal-hal berikut:

a. Syarat teknis dan perangkat keras memenuhi ketentuan dokumen persyaratan.

b. Sistem merespon secara benar untuk berbagai kondisi input yang disimulasikan. Pada tahap ini sekaligus menguji logika internal program jika terdapat kesalahan logika dengan memperhatikan luaran proses perangkat yang melenceng dari ketentuan yang diinginkan oleh konsumen yang tercatat dalam dokumen persyaratan (SRS).

c. Sistem mengeksekusi semua fungsi dalam rentang waktu operasi yang masuk akal. Pada tahap ini sekaligus akan menguji kinerja server dan konfigurasi web server dengan database system server.

d. Dapat beroperasi dalam rentang waktu perangkat lunak dibutuhkan.

e. Proses instalasi berjalan baik dan program dapat beroperasi pada lingkungan yang sesuai dengan persyaratan awal pada mula tahap analisis dan desain.

f. Memenuhi target permaslahan yang membutuhkan solusi.

Pengujian sistem dilakukan dengan menguji secara langsung fungsional sistem dengan menjalankan perangkat lunak secara online. Pengujian dilakukan terhadap 3 antarmuka aplikasi yaitu frontend, back-end dan aplikasi android.

1. Front-End

a. Halaman Utama

Halaman utama menampilkan informasi harga pangan pada hari berlangsung secara bergantian dari komoditas-komoditas pangan yang terdaftar pada sistem. Ada 3 indikator warna yaitu hijau, merah dan biru yang mewakili harga stabil, naik atau turun. Pengujian menunjukan sistem bekerja normal tanpa kesalahan logika.

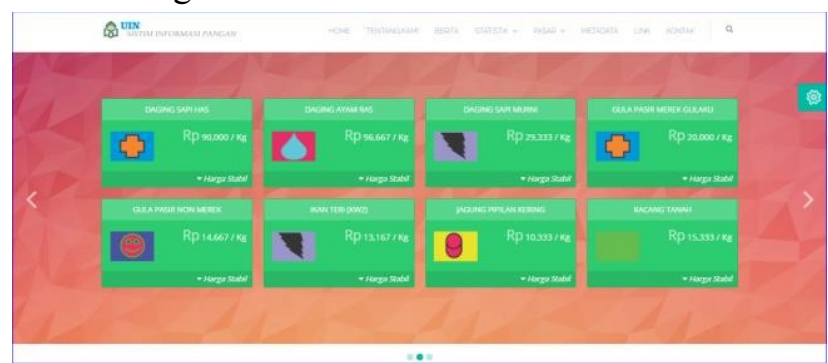

Gambar 10 Halaman Utama Front-End

b. Statistik

Pengujian halaman statistik harga yang menampilkan harga-harga pangan padan suatu tahun di pasar berbeda. 


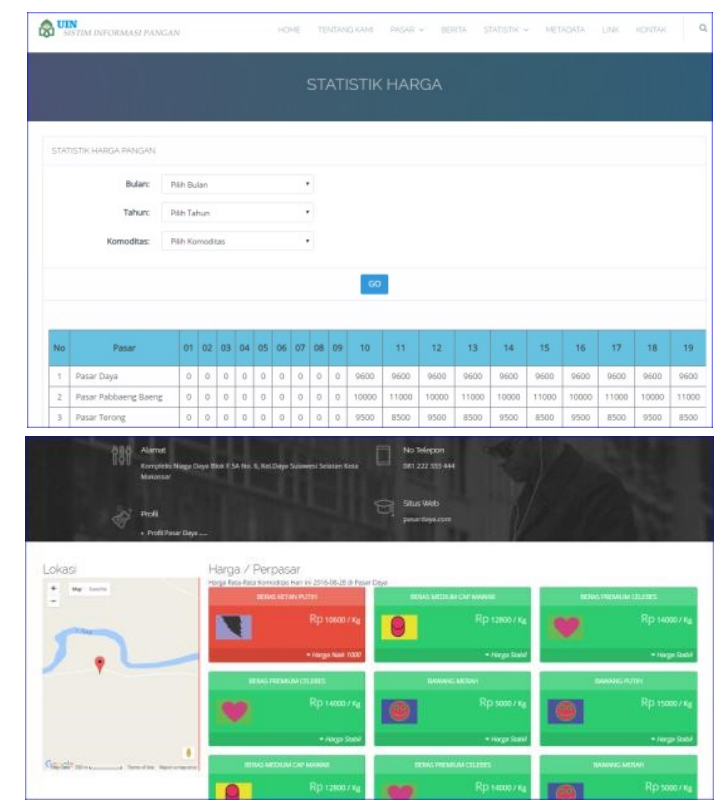

Gambar 11 Statistik Harga dan Harga Suatu Pasar

\section{c. Metadata}

File metadata tersedia dalam format PDF. Pengguna dapat mengambil data dinamis dengan memilih tanggal data pada sistem.

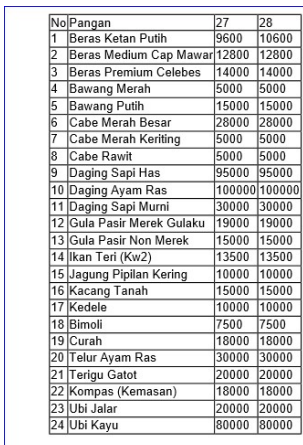

Gambar 12 Dokumen Metadata

\section{Back-End}

Pengujian halaman back-end adalah menguji fungsional akses sistem yang diperuntukan bagi operator yang bertugas sebagai administrator sistem. Ada dua antarmuka utama yaitu halaman verifikasi pengguna dan halaman dashboard yang mengelola data-data pangan. a. Login

$$
\text { Setiap akses ke halaman }
$$

dashboard pengelolaan data sistem akan dialihkan secara otomatis jika pengguna yang bersangkutan tidak atau belum pernah melakukan proses validasi akses.

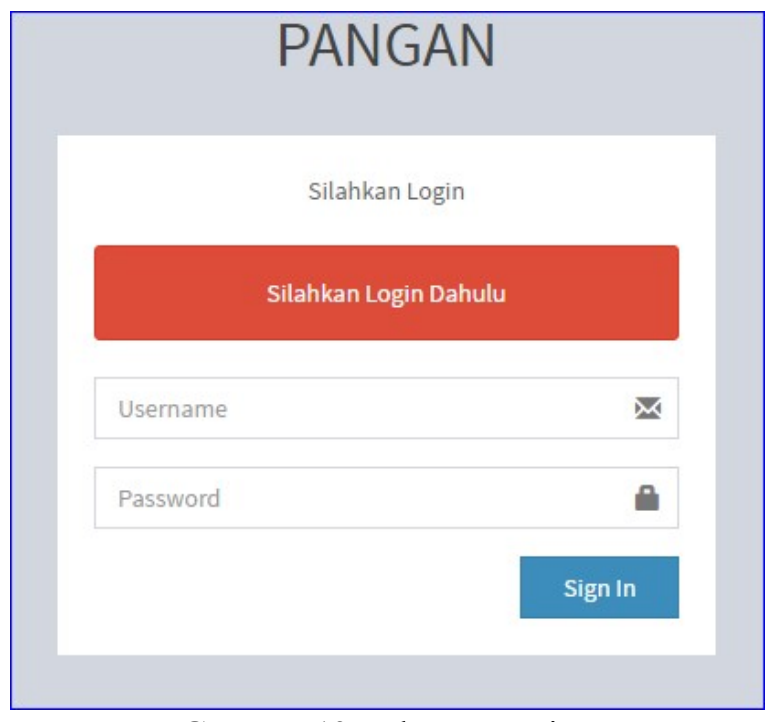

Gambar 13 Halaman Login

b. Dashboard Pengelolaan Data Pangan

Halaman Dashboard menampilkan antarmuka pengelolaan data bagi operator. Pada halaman ini, administrator sistem dapat mengatur konfigurasi sistem, menambahkan komuditas pangan atau mengatur hak akses lalu lintas data laporan harga pangan.

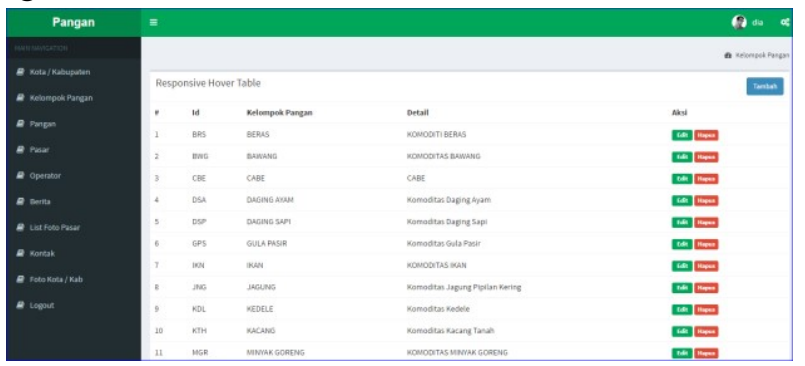

Gambar 14 Dashboard Pengelolaan Data

\section{Android}

Aplikasi android menyediakan antarmuka bagi pengguna publik untuk mengakses informasi harga pangan. Tampilan dan menu pada android berbeda dengan pada antarmuka web desktop. Menu pada aplikasi android lebih sedikit yaitu hanya tersedia menu untuk menampilkan harga perkomoditi dan harga komoditi pada pasar pilihan.

Aplikasi android memungkinkan pengguna yang memiliki mobilitas tinggi untuk mengakses harga pangan dimana saja. Platform android dipilih sebagai sistem operasi dalam percobaan penelitian ini karena pertimbangan popularitas pengguna android yang dominan di masyarakat. 


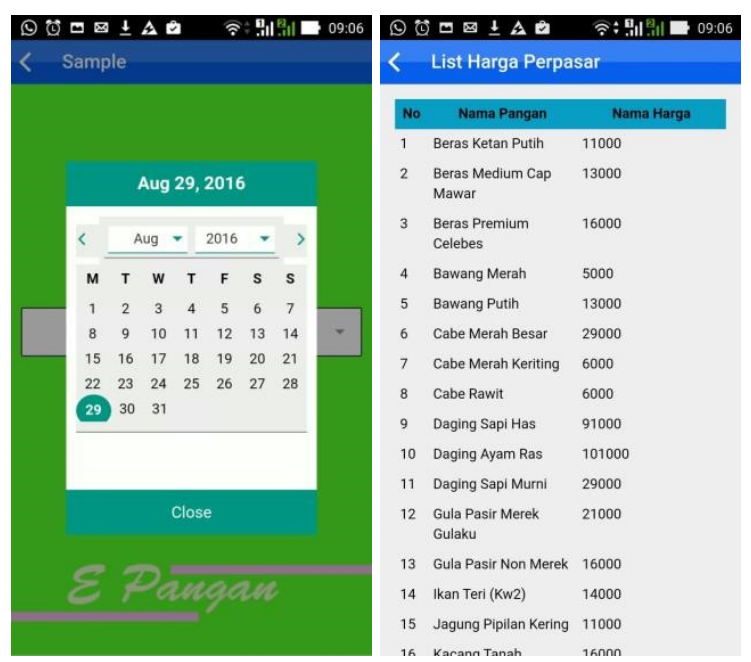

Gambar 15 Tampilan Akses dengan Android

\section{KESIMPULAN}

\section{A. Kesimpulan}

Berdsarkan hasil pengujian yang telah dilakukan, melalui pengujian black-box, tampilan dan luaran program pada 3 (tiga) antarmuka utama yakni web front-end, web back-end, dan android, dapat ditarik kesimpulan bahwa aplikasi tersebut bebas dari kesalahan logika, menyediakan tampilan akses online secara waktu nyata dengan 2 (dua) alternatif, web akses dan android apk, yang dipakai secara luas.

\section{B. Saran}

Karena keterbatasan waktu dan sumber daya analisa secara komprehensif terhadap inflasi harga di daerahdaerah belum tercakup sebagai satu kesatuan solusi aplikasi ini. Selain itu, input harga hanya mengakomodir dari jalur informasi birokrasi.Memperhatikan faktor-faktor tersebut, maka ada dua saran utama untuk tahap penelitian selanjutnya. Pertama: pengembangan database sistem sehingga menampung data pasar-pasar lokal kecil dalam kota maupun di luar daerah dengan sistem pengelompokan berdasarkan kabupaten. Penggolongan menurut kabupaten berdsar asumsi bahwa perbedaan harga karena efek inflasi sangat mungkin terjadi di kabupaten berbeda. Kedua: sistem dapat dikembangan dengan menambahkan antarmuka untuk menerima input dari umum. Sehingga siapa saja dari kalngan masyarakat dapat melaorkan harga secara saat itu juga.
Nuraeni, Yeni. 2010. Perancangan Sistem Informasi Penjaminan Mutu Perguruan Tinggi Bidang Sumber Daya Manusia. Jakarta, Indonesia.

Maulana, Miftahul dan Indra Sensure. 2011. Perancangan Strategis Sistem Informasi: Studi Kasus Direktorat Jenderal Penyelenggaraan Haji dan Umrah Departemen Agama RI. Jakarta, Indonesia.

Ibrahim, Ali. 2011. Pengembangan Sistem Informasi Monitoring Tugas Akhir Berbasis Short Message Service (SMS) Gateway di Fasilkom Unsri. Universitas Sriwijaya, Surabaya, Indonesia.

Saragih, Hoga dkk. 2012. Pengembangan Sistem Informasi Distribusi Informasi Sekolah Melalui SMSGatewaydengan Zachman Framework. Pontianak, Indonesia.

Lim, H. S. dan Wahidah Husain. 2014. A Study on Cloud Computing Adoption in E-Business. Universiti Sains Malaysia, Malaysia.

Purwasih, Nurzaitun dan Dana Indra Sensure. 2014. Pengembangan Strategi Manajemen Pengetahuan Untuk Mendukung Pelaksanaan Reformasi Birokrasi: Sebuah Studi Kasus Di Kementerian Perindustrian. Universitas Indonesia, Indonesia.

Gaol, Chr.Jimmy L. 2008. Sistem Informasi Manajemen : Pemahaman dan Aplikasi. Jakarta : PT. Gramedia Widiasarana Indonesia.

Jogiyanto, H.M. 2005. Analisis dan Desain Sistem Informasi : Pendekatan Terstruktur dan Praktik Aplikasi Bisnis. Yogyakarta : Andi Offset.

Jogiyanto, H.M. 1997. Sistem Informasi Berbasis Komputer. Yogyakarta : BPFE.

Budiyanto, Eko. 2002. Sistem Informasi Geografis Menggunakan Arcview GIS. Yogyakarta : Penerbit Andi.

Kroenke, David M. 2005. Database Processing. Bandung : Erlangga.

Nugroho “ Pemrograman Berorientasi Objek”, Buletin Jendela Informatika, vol 1 no 5 , th 2000.

Ramakrishnan, Raghu dan Johannes Gehrke. 2004. Sistem Manajemen Database. Yogyakarta : Penerbit Andi.

Velte, A. T., Velte, T. J., and Elsenpeter, R. 2010. Cloud Computing. Companies.
Practical Approach. The McGraw-Hill

\section{DAFTAR PUSTAKA}

Napitupulu, Darmawan Baginda. 2008. Sistem Informasi Pelatihan Koperasi Uji Mutu Berbasis Web. Tangerang, Indonesia. 